\title{
Assessment of pollution risk ascribed to Santa Margarida Military Camp activities (Portugal)
}

\author{
M. J. Matias $\cdot$ J. M. Marques $\cdot$ P. Figueiredo $\cdot$ M. J. Basto $\cdot$ \\ M. M. Abreu · P. M. Carreira · C. Ribeiro · A. Flambó · \\ J. Feliciano $\cdot$ E. M. Vicente
}

Received: 31 October 2007 / Accepted: 26 January 2008/Published online: 13 February 2008

(C) Springer-Verlag 2008

\begin{abstract}
Santa Margarida Military Camp (S.M.M.C.) is the only one Portuguese military training area, including firing ranges for tactical military manoeuvres of mechanised divisions. For this reason, various negative effects on the environment were expected due to the military activities, as the Military Camp's area is classified as a high vulnerability area to pollution of its multilayer porous aquifers. The aim of this study was to identify and characterise local/regional geochemical impacts caused by the continuing military training activities performed at S.M.M.C. in the course of 52 years. An overview of the geochemical research issues as a basis for risk assessment is presented. A special attention has been put on the quality of local and regional surface waters, shallow groundwaters and groundwaters. Local soils and sediments as well as fragments of shells and bullets were sampled and analysed. The results so far obtained, indicated that
\end{abstract}

M. J. Matias · J. M. Marques ( $(\bowtie) \cdot$ P. Figueiredo

M. J. Basto · E. M. Vicente

Instituto Superior Técnico, Centro de Petrologia e Geoquímica,

Technical University of Lisbon, Lisbon, Portugal

e-mail: jose.marques@ist.utl.pt

P. Figueiredo · C. Ribeiro · A. Flambó - J. Feliciano

Centro de Investigação da Academia Militar,

Lisbon, Portugal

e-mail: cip.figueiredo@sapo.pt

M. M. Abreu

Instituto Superior de Agronomia,

Technical University of Lisbon, Lisbon, Portugal

e-mail: manuelaabreu@isa.utl.pt

P. M. Carreira

Instituto Tecnológico e Nuclear, Lisbon, Portugal

e-mail: carreira@itn.pt none pollution effects were a consequence of the military training activities. Till now, the geochemical signatures such as, high levels of $\mathrm{K}, \mathrm{Cl}$ and $\mathrm{NO}_{3}$ in waters, detected in particular sites, should be faced as tracers of diffuse pollution ascribed to urban waste disposal and cattle breading.

Keywords Military training activities .

Environmental impacts · Waters · Soils · Portugal

\section{Introduction}

Santa Margarida Military Camp (S.M.M.C.) is the only one Portuguese military training area, which includes firing ranges for tactical military manoeuvres of mechanised divisions. It is situated, at $130 \mathrm{~km} \mathrm{NE}$ of Lisbon on the left bank of Tagus River (Fig. 1). The military polygonal area has an elongated and irregular shape, with $15 \mathrm{~km}$ of length (about NW-SE direction) and covering an extension of about $62 \mathrm{~km}^{2}$. It includes (1) an urban area where are located the headquarters, all the organic and residential units, barracks and support services and (2) the military training area (the most extensive) including firing ranges, a landing strip and several areas for tactical military manoeuvres of the mechanised divisions (Fig. 1).

An R\&D Project was designed to conduct appropriate research at S.M.M.C., on the impact of the military activities on the local/regional environment. In a first phase of the Project, data were gathered on the geomorphologic conditions, the geological and hydrogeological background, while in a second phase, the pollution risk was assessed. Special attention was given to the water (in particular groundwater) and soil contamination as well as landscape degradation. Other environmental problems such 
Fig. 1 Location map of the study region, with the indication of the main water sampling sites

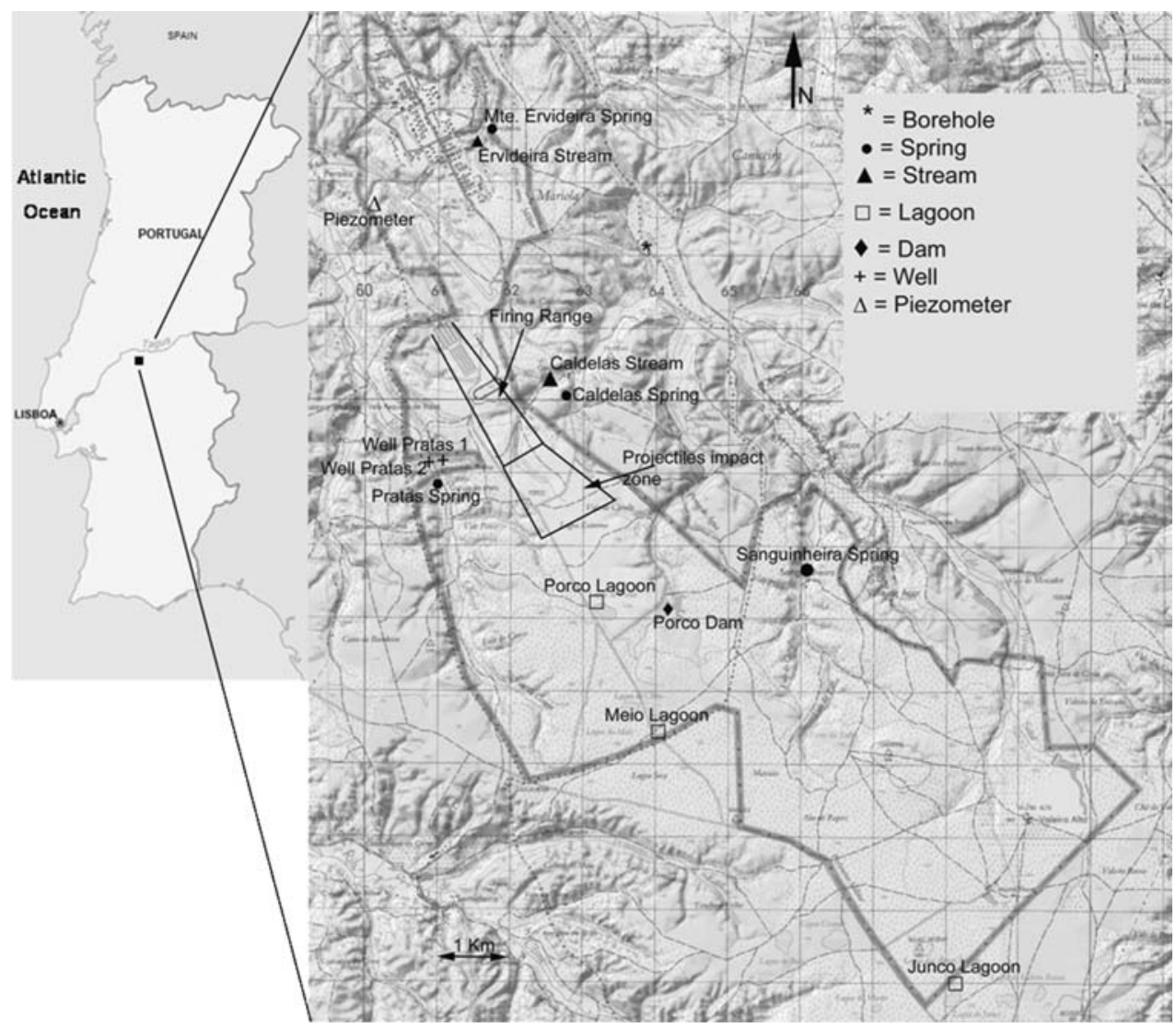

as air pollution and noise have been also considered (Serralheiro et al. 2004) but are not referred in this paper.

Furthermore the Unit/Subunit Commanders of S.M.M.C. were also focused in the assessment of the damage caused by military activities and were interested in developing better environmental practices (Ramos and Melo 2004). Wastewater treatment, noise control, ecosystem conservation had been already implemented. Among other educational activities, the Commander of S.M.M.C. organize, every year, an "Environmental Week", with invited researchers to present and debate environmental questions.

It should be stated that the selection of the area for this Military training Camp, 52 years ago, was based on the following criteria: cheap land value, soils with lower agricultural productivity, natural land features for training and a relatively flat landscape which reduces the need to land movements (Callado 1953).

At that time, these and other criteria taken into consideration (mostly of economic concerns) were also acceptable from an environmental point of view. During the Camp's lifetime, its Command Posts have adopted the same economic and environmental concerns. As the Camp is a military training area, trails have been opened in order to allow the circulation of vehicles and to restrain the destruction of the vegetation.
Special precautions are also taken during the forest fires season to avoid fires and consequent destruction of vegetation. Furthermore, another positive environmental impact of this area's occupation by the Military training Camp is the conservation of several temporary ponds (referred as lagoons along the text) which harbour ecosystems of great interest due to the rare species which inhabit these areas. These lagoons, varying in size, between 150 and $300 \mathrm{~m}$ of maximum wide and with an area of about $0.1-0.9 \mathrm{~km}^{2}$, are in excellent state of preservation (Rosselló-Graell et al. 2000). In other regions of the World, agriculture has been a great risk for similar lagoons (Beja and Alcazar 2003). The modification of the hydrological system causes a negative effect on the biodiversity of the lagoon's ecosystems. Usually, such modifications result from drainage, land levelling, contamination with pesticides and fertilizers and, their transformation into permanent water reserves.

The S.M.M.C. is situated, on a plateau area, in the Lower Tagus Tertiary Basin (Central Portugal), the most extensive and important Portuguese multilayered aquifer system. The rill erosion is very intense on the barren slopes and is frequent the formation of large gullies and temporary stream channels. The bottom of these channels is coarse gravel. The trail's construction, mainly down the slopes, also increases the erosion process. 
The lithological substrate is mostly constituted by fluvial sedimentary deposits, conglomerates and reddish to yellowish clay sandstones, which were deposited over the ancient estuary (Pre-Tagus) and over the Miocene and Pliocene sediments (Almeida et al. 2000). This Tertiary deposits overlays, discordantly, the Precambrian rocks which emerges in several points of Camp's area, in the deepest stream channels. The Precambrian is constituted by gneissic and migmatitic formations and granites of Ossa Morena Zone. The most recent formations are Quaternary deposits, occurring, in the fluvial terraces, being mostly formed by sands and gravels beds.

The hydrogeological unit is constituted mainly by sandstones, which alternate with impervious clay layers. The fact of existing recurrence of pervious and impervious lenticular layers, the permeability of the unit is very variable. At surface, there are sands, in some places with a significant percentage of clay where the lagoons occurred (Gonçalves et al. 1979; Zbyzewski and da Veiga Ferreira 1979).

The S.M.M.C. is located in a temperate region with typical Mediterranean climate characteristics: hot and dry summers and wet and moderate winters. Average annual precipitation value is $828 \mathrm{~mm}$, being the rainfall more intense in December and January. In the driest monthsJuly and August - the average precipitation value is $5 \mathrm{~mm}$ per month (Loureiro and van Zeller de Macedo 1986). From April to July the prevailing winds are from the northwest, presenting a predominantly E-NE direction in October. Average wind speed varies from 7 to $10 \mathrm{~km} / \mathrm{h}$. Strong windy days are less frequent.

The majority of the terrain is a Heathland habitat-a type of landscape characterized by sandy and dry soils, and shrub vegetation like gorse, heather, heath and broom shrub-with some patches of Montado ecosystems (protected by the Portuguese legislation), olive and pine trees (Callado 1953). A large variety of animals (birds and mammals) have found natural refuge in the military area because hunting is strictly forbidden.

The aim of this study was to identify and characterise local/regional geochemical impacts caused by the continuing military training activities performed at S.M.M.C. in the course of 52 years.

\section{Materials and methods}

The preliminary field work campaigns have been planned in order to cover, as much as possible, all the Military Camp area and respective surroundings, with the aim to (1) assess the geochemical and isotopic signatures of local surface waters and groundwaters, (2) acquire sensibility for the results interpretation and (3) to detect some tendencies, in order to plan future field work campaigns.

Springs, streams, temporary lagoons, wells and an extraction borehole, located in the neighbouring (inside and outside) of the training area, were selected as water sampling sites. Samples of superficial soils and sediments were also collected, and some metallic fragments of munitions (fragments of shells and bullets) were picked up at the soil's surface.

Seasonal field-work campaigns were performed and the sampling sites were selected in order to assess hydrogeological information using the following criteria:

1. The land use (e.g., projectiles impact zones, circulation tracks of military vehicles, urban waste disposals, and also on scrub areas on which heath naturally grow);

2. The landscape morphology.

Water physico-chemical properties ( $\mathrm{T}, \mathrm{pH}, \mathrm{Eh}, \mathrm{EC})$ were measure in situ. Total alkalinity, major, minor and trace elements and, isotopic $\left(\delta^{18} \mathrm{O}, \delta^{2} \mathrm{H}\right.$ and $\left.{ }^{3} \mathrm{H}\right)$ composition of the waters were determined at the laboratory.

The chemical analyses were performed at Laboratório de Mineralogia e Petrologia of Instituto Superior Técnico (LAMPIST/Portugal) using atomic absorption spectrometry for $\mathrm{Ca}$ and $\mathrm{Mg}$; emission spectrometry for $\mathrm{Na}, \mathrm{K}$, $\mathrm{Li}, \mathrm{Rb}$ and $\mathrm{Cs}$; colorimetric methods for $\mathrm{SiO}_{2}, \mathrm{Fe}_{\text {total }}$, $\mathrm{F}$ and $\mathrm{Al}$; ion chromatography for $\mathrm{SO}_{4}, \mathrm{NO}_{3}$ and $\mathrm{Cl}$; potentiometry for alkalinity, here referred to as $\mathrm{HCO}_{3}$ concentrations.

The $\delta^{2} \mathrm{H}$ and $\delta^{18} \mathrm{O}$ measurements (vs. V-SMOW, Vienna Standard Mean Ocean Water) were performed by mass spectrometry (SIRA 10-VG ISOGAS) at Instituto Tecnológico e Nuclear (ITN/Portugal), following the analytical methods of Epstein and Mayeda (1953) and Friedman (1953), with an accuracy of $\pm 1.0 \%$ for ${ }^{2} \mathrm{H}$ and $\pm 0.1 \%$ for ${ }^{18} \mathrm{O}$. The ${ }^{3} \mathrm{H}$ water content (reported in Tritium Units, TU) was also determined at ITN, using electrolytic enrichment followed by liquid scintillation counting method (standard deviation varies between \pm 0.9 and $\pm 1.3 \mathrm{TU}$, depending on tritium activity). The analytical method is described in IAEA (1976).

Soil samples have been collected for (1) particle size distribution (sand, silt and clay fractions), (2) chemical composition and (3) mineralogy of the clay fraction. Different analytical methods had been used: sieving and sedimentation according to Stokes law for granulometry, $\mathrm{X}$-ray diffraction and IR spectrometry for the mineralogical identification; FRX spectrometry for the chemical (elemental) analysis of soil's clay fraction.

The fragments of shells and bullets were sampled and analysed by FRX spectrometry for qualitative elemental analysis. 


\section{Results and discussion}

Hydrogeochemical approach

Representative physico-chemical signatures of the sampled waters are presented in Table 1.

From the observation of the Piper diagram of Fig. 2 one can conclude that most of the sampled waters present rather similar geochemical signatures: $\mathrm{Cl}$ and $\mathrm{Na}$ are the dominant ions.

In order to evaluate, in a expedite way, the total mineralization of the waters, the electrolytic conductivity (EC) was measured, in situ. This physical water property usually is a good indicator of eventual problems of water mineralization that could be ascribed to anthropogenic contamination. The diagram of Fig. 3, shows that the highest values of EC are only ascribed to Ervideira stream, Ervideira spring, the water sampled in the monitoring well down of the sanitary landfill disposal site, referred as the piezometer, and the borehole AC5, referred as the extraction borehole. All the other sampled waters presented lower EC values and can be classified as "normal" waters.

The high EC values presented by Ervideira stream and spring should be faced as an indicator of anthropogenic contamination. The hypothesis of water-rock interaction to explain the high EC values detected in Ervideira stream and spring should be excluded since the lithology of the study region is rather similar and the other stream and shallow groundwaters do not present such high EC values. The high EC value observed in the water from the well located down the landfill disposal site is also ascribed to the local contamination. In the case of the water from the extraction borehole AC5, the high value of EC $(677 \mu \mathrm{S} / \mathrm{cm})$ is explained by the deep circulation of these waters and consequent extended water-rock interaction.

The contamination of anthropogenic origin (agriculture and/or cattle breading activities, Fig. 4) detected in the waters of Ervideira stream and Ervideira spring is revealed by the high $\mathrm{K}, \mathrm{Ca}, \mathrm{Cl}, \mathrm{SO}_{4}$ and $\mathrm{NO}_{3}$ concentrations (Table 1), usual components of the most common fertilisers and manure.

On the other hand, the strong mineralization of the groundwaters from borehole AC5 (150 m depth; Table 1) should be ascribed to water-rock interaction as the result of a deeper circulation and to the leach of salts included in the gravel beds at depth.

Surface waters presented $\mathrm{pH}<7$ and are characterised by very low mineralization $(\mathrm{EC} \approx 45 \mu \mathrm{S} / \mathrm{cm}$ ). The Meio and Porco lagoons and Porco dam are located within, or very close, to the present-day projectile's impact area. The water from these lagoons presented $\mathrm{Al}, \mathrm{Fe}$ and $\mathrm{Cr}$ values relatively higher than the other surface waters. The source of the high $\mathrm{Fe}$ concentrations in the water of Caldelas stream is not yet completely understood.

In the case of Coruja do Pratas well the Fe values can be ascribed to the well's metallic structures, which presented a high degradation stage.

The water, during its flow trough soils can pick up elements, resulting in contamination of the groundwater resources (Carsel and Parrish 1988). Some of the collected soils were loamy sand soils with clay fraction $<100 \mathrm{~g} / \mathrm{kg}$. The fraction $>2 \mathrm{~mm}$ is composed by quartz and quartzite. Micaceous minerals, $\mathrm{K}$ and $(\mathrm{Na}, \mathrm{Ca}$ ) feldspars and $\mathrm{Fe}-\mathrm{Mn}$ oxides are also present in soil's silt and clay fractions. Kaolinite and illite are the main phyllosilicates present in clay fraction.

Among the heavy metals identified in the soil's clay fraction $\mathrm{Fe}$ is always present and the most abundant. Lead, $\mathrm{Zn}, \mathrm{Cu}$ and $\mathrm{Mn}$ were also identified, but at lower levels. Chromium was sometimes present.

The soil colleted next the vehicle repair shop, presented special characteristics. It was a dark soil, contaminated by the presence of polycyclic aromatic hydrocarbons $(4 \mathrm{mg} /$ $\mathrm{kg}$ ), and with high levels of $\mathrm{Cd}(33 \mathrm{mg} / \mathrm{kg}), \mathrm{Pb}(283 \mathrm{mg} /$ $\mathrm{kg})$ and $\mathrm{Zn}(398 \mathrm{mg} / \mathrm{kg})$. All the other heavy metals analysed display values accepted for non-ontaminated soils (Visser 1994).

The sediments deposited in the bottom of the temporary lagoons were also analysed. The same heavy metals were present: $\mathrm{Zn}, \mathrm{Cu}, \mathrm{Mn}, \mathrm{Cr}, \mathrm{Pb}$ and $\mathrm{Fe}$, being this last element the most abundant.

Some fragments of shells and bullets picked up in the soils from the impact areas were also analysed. These materials showed different chemical compositions. The fragments of shells present $\mathrm{Zn}$ and $\mathrm{Cu}$ as the most abundant metals, followed by Fe. The bullets present Fe as the most abundant component, followed by $\mathrm{Mn}$ and $\mathrm{Al}$. Chromium was never identified in these materials.

\section{Environmental isotopes approach}

Coupled geochemical and environmental isotopic techniques have provided important information to answer the most usual questions associated with hydrogeological studies, namely: (1) the origin of the different types of waters (2) the underground flow paths, and (3) the mixing processes in the system.

Environmental isotopes contributed to the present understanding of the nature of groundwaters of the Military Camp. In this chapter is discussed the use of stable isotope ratios $\left({ }^{2} \mathrm{H} /{ }^{1} \mathrm{H}\right.$ and $\left.{ }^{18} \mathrm{O} /{ }^{16} \mathrm{O}\right)$ and radioactive $\left({ }^{3} \mathrm{H}\right)$ isotopes to address questions associated to recharge, flow systems and mixing processes, emphasising that investigations that uses isotopic data integrated with geochemical data usually 


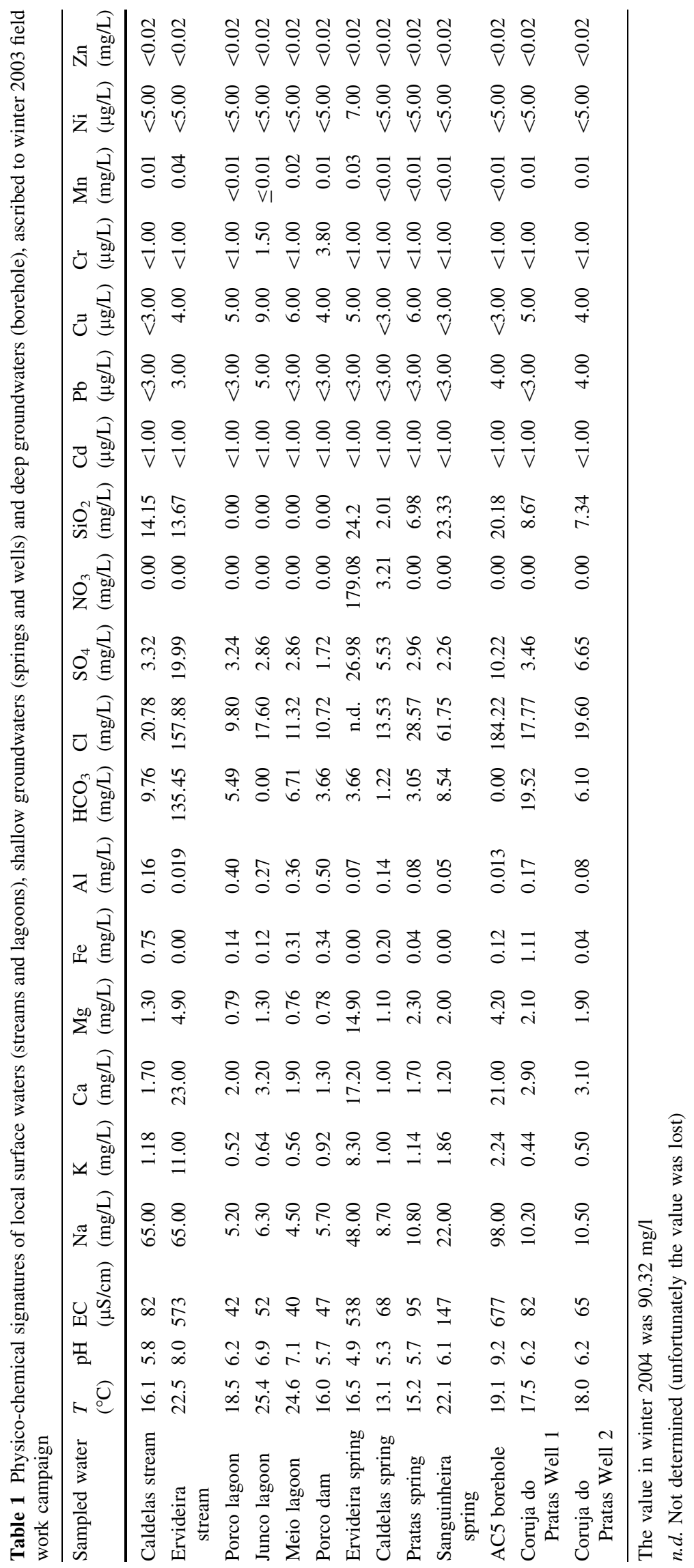


Fig. 2 Piper diagram for the studied surface waters (streams, lagoons, and dam), shallow groundwaters (wells and piezometer) and groundwaters (borehole)

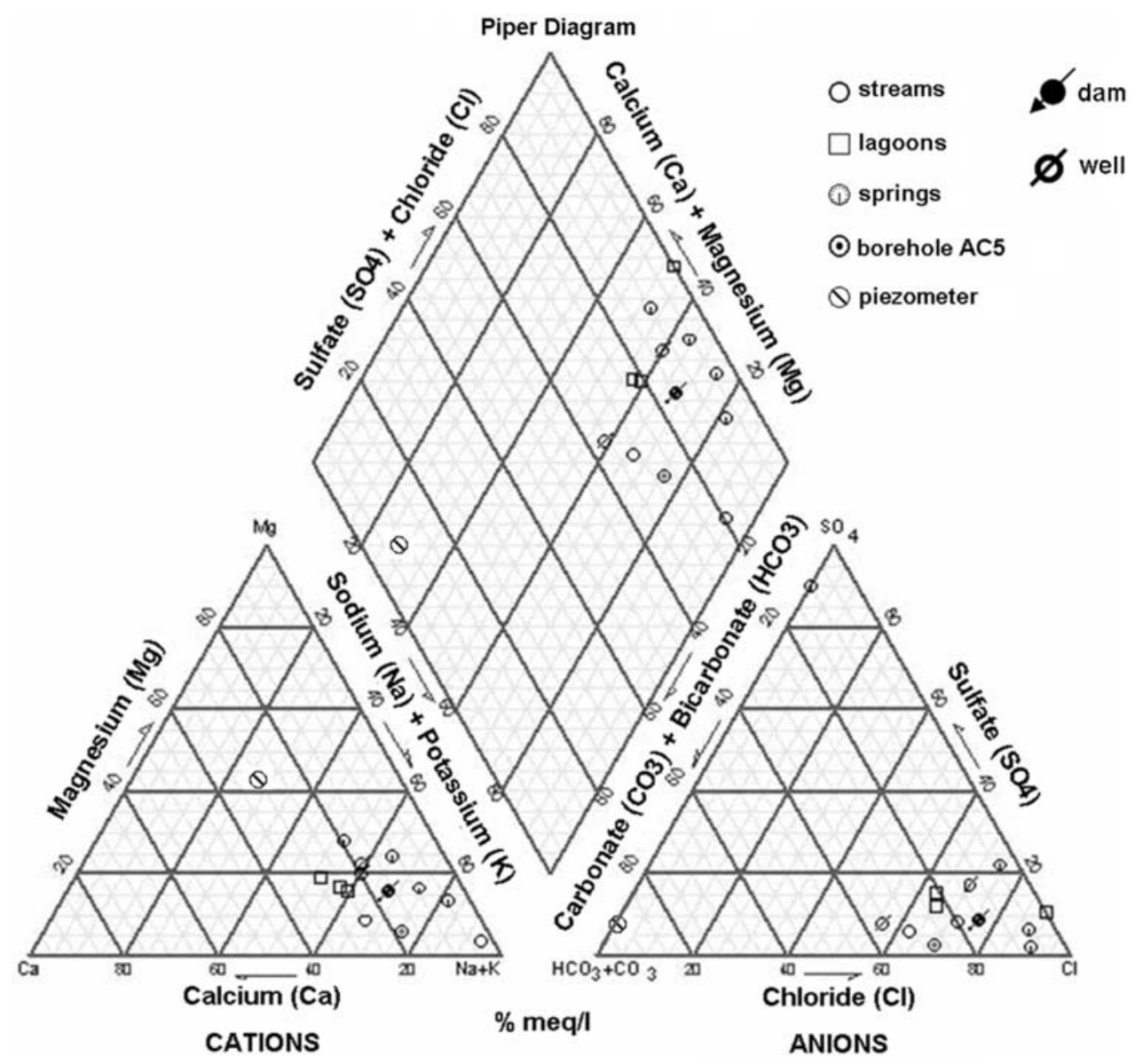

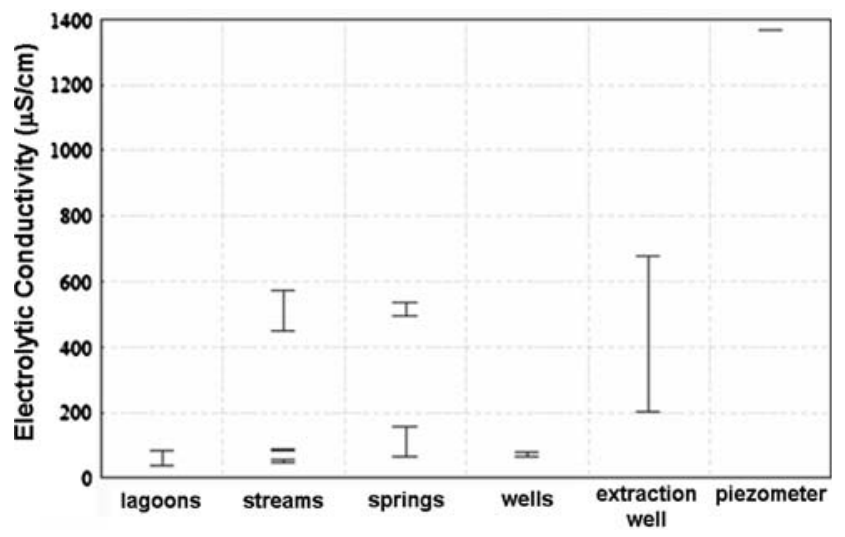

Fig. 3 Electrolytic conductivity values presented by the studied surface waters, shallow groundwaters and groundwater samples

produce more important results (Kendal and Caldwell 1998).

The isotopic compositions of hydrogen and oxygen in precipitation are covariant. This relationship is commonly represented by the World Meteoric Water Line (WMWL): $\delta^{2} \mathrm{H}=8 \delta^{18} \mathrm{O}+\mathrm{d}$, where $\mathrm{d}$ is the so-called deuterium excess. Craig (1961) found that the global mean value of $d$, in the case of natural waters, was $+10 \%$.

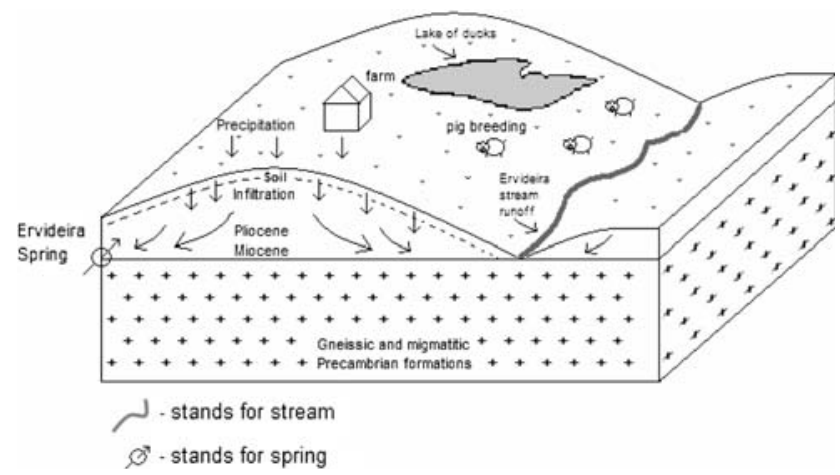

Fig. 4 Conceptual hydrogeological model of Monte da Ervideira area

In the present case study, the data presented in Fig. 5 seems to reveal the existence of two water groups. One of the groups (A) includes local surface waters (dam and stream waters) and groundwaters (sampled from wells, a borehole, springs and a piezometer). This group of waters is plotted close and along to the World Meteoric Water Line, indicating that they are meteoric waters which have not been subjected to evaporation (IAEA 1981; Hoefs 1997), being directly infiltrated into the ground. The Local Meteoric Water Line (LMWL) was established using all 
the available data from local surface waters (dam and stream waters) and groundwaters (sampled from wells, a borehole, springs and a piezometer). The obtained equation of LMWL was: $\delta^{2} \mathrm{H}=6.15 \quad \delta^{18} \mathrm{O}-1.61 \quad(n=12$; $r^{2}=0.78$ ). The slope of the LMWL indicates that these waters are not evaporated and that the deuterium excess could be ascribed to local climatic factors. The water sample from the dam was collected $5 \mathrm{~m}$ below the surface using a special device. So, isotopic fractionation related to evaporation, if occurred, should be extremely small. On the other hand, in the lagoons the water depth sometimes has no more than $0.5 \mathrm{~m}$.

The other "group" (B) is ascribed to waters sampled in the lagoons (e.g., Porco lagoon, Meio lagoon and Juncos lagoon). This group is not homogeneous. Each lagoon presents its own way of evaporation. As an example, in Fig. 5 is presented the evaporation trend of Porco lagoon.

No evidence of mixing between these two water groups (lagoons and the other water samples) has been identified. In case of occurring mixture between these two water bodies it should be detected by the projection of several water points between the two end-members (Fig. 5).

Tritium $\left({ }^{3} \mathrm{H}\right)$ is the radioactive isotope of hydrogen, presenting a half-life of 12.32 years (IAEA 1983). It is incorporated in the water molecule, and so is an ideal tracer for groundwater dating. When used as a tracer, ${ }^{3} \mathrm{H}$ is especially suitable for dynamic modelling of shallow groundwater systems, which usually are characterised by the presence of recently recharged water. Tritium concentrations are expressed as tritium units (TU) where $1 \mathrm{TU}=1{ }^{3} \mathrm{H}$ atom per $10^{18}{ }^{1} \mathrm{H}$ atoms. The role of ${ }^{3} \mathrm{H}$ as an environmental tracer in the hydrological cycle is directly ascribed to the large quantities of tritium introduced by atmospheric thermonuclear testing in the 1950s and 1960s.

In the present paper, tritium data of surface waters, shallow groundwaters and groundwaters was used in a qualitative way, bearing in mind that for continental regions (Clark and Fritz 1997):

$<0.8 \mathrm{TU}$ sub-modern-recharge prior to 1952 ;

0.8 to mixture between sub-modern and recent $\approx 4 \mathrm{TU}$ recharge;

$5-15 \mathrm{TU}$ modern $(<5-10$ years);

15-30 TU some "bomb" tritium present;

$>30 \mathrm{TU}$ considerable component of recharge from 1960s or 1970s;

$>50$ TU dominantly the 1960s recharge.

The term "age of a groundwater" should only be applied in regional confined aquifers. Therefore, it is common to use the term "groundwater mean residence times" instead of "age of a groundwater". However, in this paper the term "age" will be used since many other authors have commonly adopted it (Cook and Herczeg 2000).

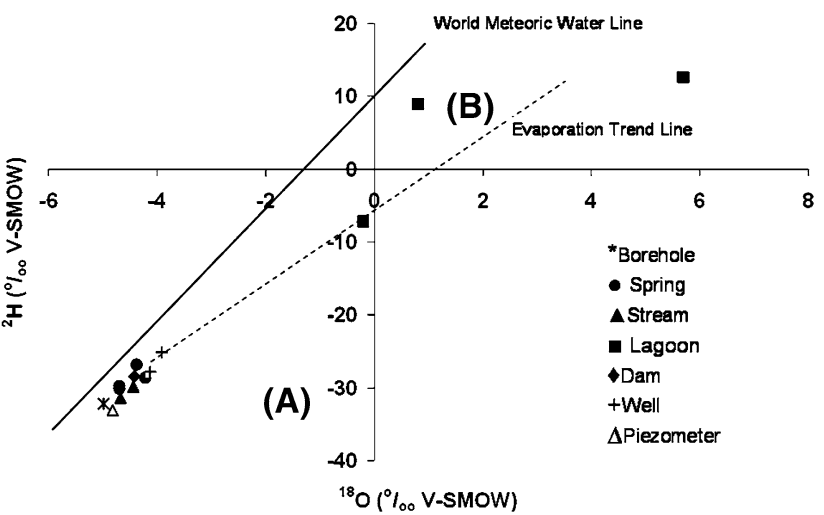

Fig. $5 \delta^{2} \mathrm{H}$ versus $\delta^{18} \mathrm{O}$ diagram for the studied waters

Concerning ${ }^{3} \mathrm{H}$ concentrations, the studied waters can be separated into two main groups (Fig. 6):

1. The waters sampled from streams, springs, wells and lagoons, are characterized by ${ }^{3} \mathrm{H}$ values between 1.6 and $3.8 \mathrm{TU}$.

2. The waters from borehole AC5, characterized by low ${ }^{3} \mathrm{H}$ concentrations ascribed to a deep and longer underground flow path, when compared with the other shallow groundwaters of the study region.

The ${ }^{3} \mathrm{H}$ values (TU) present in waters from streams, springs, and wells are similar to those found in present day atmospheric precipitation in Portuguese mainland (Carreira et al. 2005), indicating that they are recent meteoric waters ascribed to a local recharge and circulation paths.

From the diagram of Fig. 7, one can observe that the waters with high $\mathrm{Cl}$ concentrations (borehole AC5 and Ervideira stream) display different ${ }^{3} \mathrm{H}$ signatures $(0.6$ and $2.3 \mathrm{TU}$, respectively), indicating two different sources for

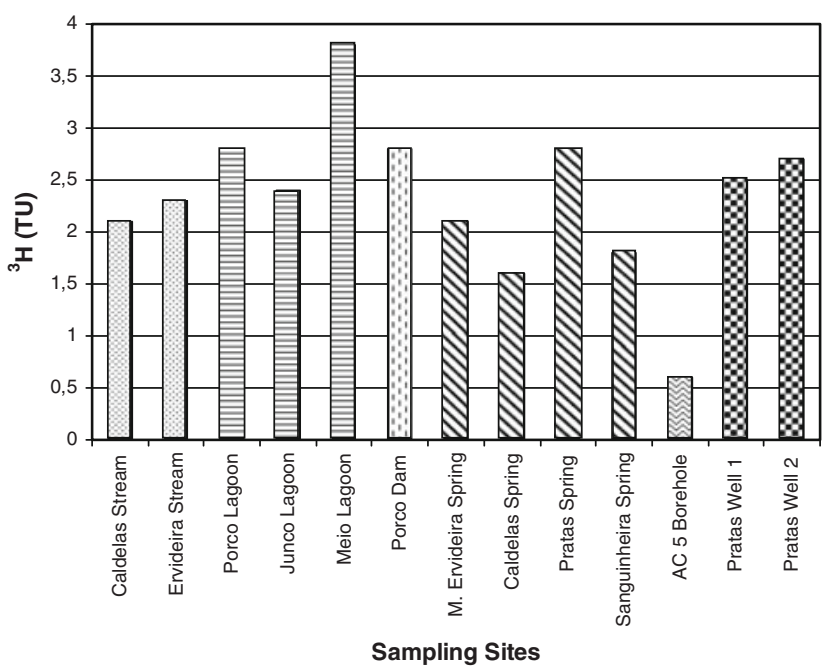

Fig. 6 Tritium concentrations (TU) in surface waters and groundwaters of the studied region 


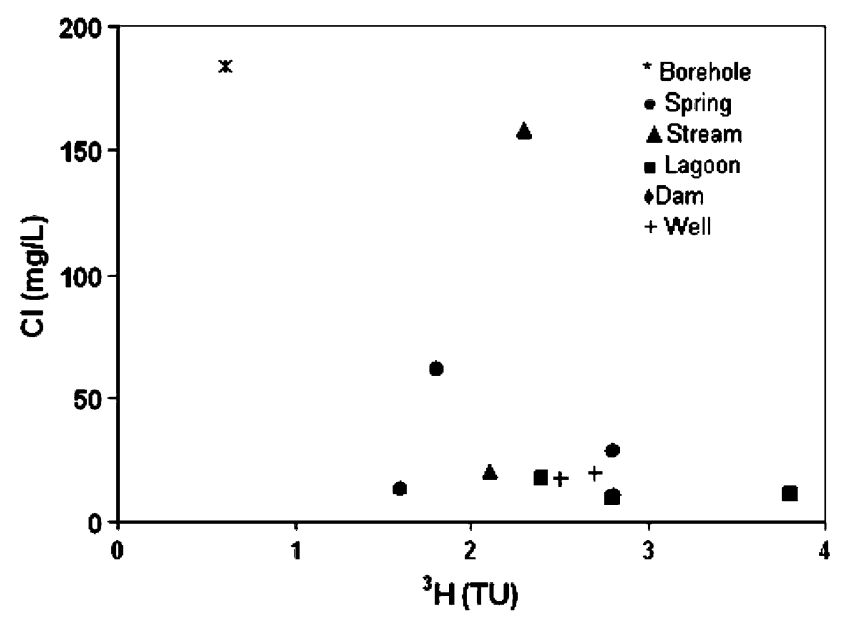

Fig. $7 \mathrm{Cl}$ versus ${ }^{3} \mathrm{H}$ diagram for the studied waters

the $\mathrm{Cl}$ in those waters. In the case of Ervideira stream, the ${ }^{3} \mathrm{H}$ concentration indicates that the stream waters are recent meteoric waters being the high $\mathrm{Cl}$ concentration $(\approx 160 \mathrm{mg}$ / L) probably the result of anthropogenic contamination.

In the case of the waters from borehole $\mathrm{AC} 5$, the $\mathrm{Cl}$ concentration is also high $(\approx 180 \mathrm{mg} / \mathrm{L})$ but the ${ }^{3} \mathrm{H}$ concentration is very low (close to the detection limit). These results seem to corroborate the idea that the waters from borehole AC5 are "old" groundwaters where the high mineralization should be faced as the result of a deeper circulation path through the subsurface rocks.

In the case of Ervideira spring and stream, the ${ }^{3} \mathrm{H}$ concentrations in the order of $2 \mathrm{TU}$ indicate that the incorporation of $\mathrm{Cl}, \mathrm{K}, \mathrm{Ca}$ and $\mathrm{SO}_{4}$ into the aqueous system is relatively fast, since they are recent meteoric waters with small surface and shallow flow paths, respectively.

\section{Concluding remarks}

In this Military training Camp the Unit/Subunit Commanders are strongly interested in developing better environmental practices. Coupled geochemical and isotope techniques have greatly contributed to assessment of the possible damage caused by the military training activities at S.M.M.C.

In S.M.M.C., environmental problems have been mainly identified in the Ervideira area, where the surface waters (from the stream) and the shallow groundwaters (from the spring) present evidences of anthropogenic contamination, and remediation measures were recommended. Besides, Ervideira area is located next to the water residue treatment station and will be easy to piping the water from the stream to that treatment station.

The results so far obtained indicate that the signatures of anthropogenic contamination found in the Military Camp are mainly the result of diffuse pollution ascribed to: some particular urban waste disposal, pasture ground, a small duck's lagoon, poultry farming and cattle breeding.

The results obtained under the scope of the Project " $\mathrm{O}$ campo de treino militar de Santa Margarida: estudo do impacto ambiental após meio século de utilização" have contributed to improve the Environmental Management System of Santa Margarida Military Camp, which is nowa-days certificated by the Portuguese Association of Certification (APCER), as an Institution Certified by the Norms NP EN ISO 14001:1999. This certification is synonymous of a worthy concern towards the preservation of 6,400 ha of the Santa Margarida Military Camp, including magnificent forest areas with important species of wildlife that have lived peacefully with the activities inherent to the field, since its foundation, precisely 52 years ago. The environmental management system allows establishing an appropriate policy to its own reality by adopting solutions that aim to reduce the costs and risks of their operation, highlighting a better image of the military establishment, as well as a reference and an example of encouragement for the remaining units of the Army.

Acknowledgments This work was performed under the scope of the R\&D Project "O campo de treino militar de Santa Margarida: estudo do impacto ambiental após meio século de utilização", Contract No. O 603, funded by the Ministry of National Defence. We would like to thank the Portuguese Army and its Santa Margarida Unit, for the help in the fieldwork campaigns and for their co-operation in the execution of this project. We also would like to thank Gonçalo Barral for his contribution during part of the Project's execution period. An early draft of this manuscript was critically read by two anonymous reviewers and we gratefully acknowledge their contribution.

\section{References}

Almeida C, Jesus MR, Mendonça JJL, Gomes AJ (2000) Sistemas aquíferos de Portugal continental - Sistema Aquífero das Aluviões do Tejo (Aquifer systems in Portuguese mainland Aquifer System of Tagus alluvium deposits). INAG, $\mathrm{p} 12$

Beja P, Alcazar R (2003) Conservation of Mediterranean temporary ponds under agricultural intensification: an evaluation using amphibians. Biol Conserv 114(3):317-326

Callado JAS (1953) Campo de Instrução Militar de Sta. Margarida (Sta. Margarida's Military Instruction Camp). Revista de Engenharia Militar, Ano 24, 11:251-268

Carreira PM, Araújo MF, Nunes D (2005) Isotopic composition of rain and water vapour samples from Lisbon region-characterization of monthly and daily events. In: IAEA (eds) Isotopic composition of precipitation in the Mediterranean basin in relation to air circulation patterns and climate. IAEA-TECDOC 1453:141-155

Carsel FF, Parrish RS (1988) Developing joint probability distributions of soil water retention characteristics. Water Resour Res 24(5):755-769

Clark I, Fritz P (1997) Environmental isotopes in hydrogeology. Lewis Publishers, New York, p 327

Cook P, Herczeg AL (2000) Environmental tracers in subsurface hydrology. Kluwer, Boston, p 529 
Craig H (1961) Isotopic variations in meteoric waters. Science 133:1703-1704

Epstein S, Mayeda T (1953) Variation of ${ }^{18} \mathrm{O}$ content of waters from natural sources. Geochim Cosmochim Acta 4:213-224

Friedman I (1953) Deuterium content of natural waters and other substances. Geochim Cosmochim Acta 4:89-103

Gonçalves F, Zbyzewski G, Carvalhosa A, Coelho AP (1979) Notícia explicativa da Carta Geológica de Portugal na escala 1/50 000, Folha 27-D (Descriptive notes of the Geological Charter of Portugal in the scale 1/50 000, Sheet 27-D). Serviços Geológicos de Portugal, Lisboa, p 75

Hoefs J (1997) Stable isotope geochemistry, 4th edn (completely revised, updated, and enlarged). Springer, Berlin, p 201

IAEA (International Atomic Energy Agency) (1976) Procedure and technique critique for tritium enrichment by electrolysis at IAEA laboratory. In: IAEA (eds) Technical procedure no 19, Vienna, p 30

IAEA (International Atomic Energy Agency) (1981) Stable isotope hydrology. Deuterium and oxygen-18 in the water cycle. IAEA, Vienna, Technical reports series 210, p 339

IAEA (International Atomic Energy Agency) (1983) Guidebook on nuclear techniques in hydrology. IAEA, Vienna, Technical reports series 91, p 439

Kendal C, Caldwell EA (1998) Fundaments of Isotope Geochemistry. In: Kendal C, McDonnell JJ (eds) Isotope tracers in catchment hydrology. Elsevier, New York, pp 51-86

Loureiro JJM, van Zeller de Macedo MA (1986) Bacia Hidrográfica do Rio Tejo. In: Monografias Hidrológicas dos Principais Cursos de Água de Portugal Continental. Direcção Geral dos Recursos e Aproveitamentos Hidráulicos (Tagus river basin. In: Hydrologic monographs of main water courses of Portuguese mainland. Directorate General of Water Resources Tapping) Lisboa, 281337

Ramos TB, Melo JJ (2004) Environmental management practices in the defence sector: assessment of the Portuguese military's environmental profile. J Cleaner Prod 13:1117-1130

Rosselló-Graell A, Draper D, Tauleigne Gomes C (2000) Conservation status of Mediterranean temporary ponds in Campo Militar de Santa Margarida (Ribatejo, Portugal). Port Acta Biol 19:191199

Serralheiro JA, Ribeiro C, Figueiredo P (2004) Estudo preliminar sobre o impacto acústico de exercícios de fogos reais no Campo Militar de Santa Margarida (Preliminary study on the acoustic impact ascribed to real fire exercises in the Santa Margarida Military Camp). Proelium Rev Acad Militar VI Ser 2:191-201

Visser WJF (1994) Contaminated land policies in some industrialized countries, 2nd edn. Technical Soil Protection Committee, The Hague, p 149

Zbyzewski G, da Veiga Ferreira O (1979) Notícia explicativa da Carta Geológica de Portugal na escala 1/50 000. Folha 31-B (Descriptive notes of the Geological Charter of Portugal in the scale 1/50 000, Sheet 31-B). Serviços Geológicos de Portugal, Lisboa, p 27 